\title{
The Role of Web-based Language Teaching on Vocabulary Retention of Adult Pre-intermediate EFL Learners
}

\author{
Mustapha Hajebi \\ Department of Education, Bandar Abbas, Iran \\ SeddiQ Taheri \\ Yazd University, Yazd, Iran \\ Farhad Fahandezh \\ Islamic Azad University of Bandar Abbas, Iran \\ Hosain Salari \\ Islamic Azad University of Bandar Abbas, Iran
}

\begin{abstract}
This research is done to prove the effect of web-based language learning on the vocabulary improvement of the subjects of the study and to seek the attitudes of the learners on the use of web-based approach in the language class. In order to ensure the homogeneity of the students, a modified Michigan test (version1997) was presented and students were divided into one experimental group $(n 1=33)$ who learned their course vocabularies making use of free vocabulary learning sites of IELTS English language learning site every day for 8 weeks and one control group $(\mathrm{n} 2=33)$ who received ordinary classroom instructions each session. The result appeared to manifest that learners' perception improve by incorporating web based instruction in language learning classroom. It also indicated a significant difference between experimental and control group with regard to their vocabulary knowledge. WBL instruction enhanced EFL learners' vocabulary knowledge. The findings of this study may offer some implications for language teaching and learning. To begin with, these findings can be beneficial for language learning curriculum designers to present tasks that enrich both the language of the students and their motivation to apply on-line web sites for autonomous learning of language.
\end{abstract}

Index Terms-EFL learners' performance, vocabulary retention, web-based instruction

\section{INTRODUCTION}

Online courses and web-based learning and teaching modes have been employed more and more due to the current dramatic advances in computer technologies. This process helps to exchange information between instructors and students, and between students and their peers. The learning process in this way permits learners to have more freedom to monitor their learning without the limitations of considering by other learners or instructor, time and space. Also, the learners can specify when to participate in the activities (Khany \& Khosravian 2014).

Shi et al. (2006) stated that one of the main benefits of web-based language learning is students' convenience. This kind of convenience may become very precious for most adult EFL learners since they are often busy with their jobs. Furthermore, within a web-based learning students can rely on themselves simply because of waiting to be on online seems not to be available for teachers. This also enhances second/foreign language learners' personal ability in learning (Khany \& Khosravian 2014).

Web-based instruction activities have also left their positive impact on L2 vocabulary learning process. The results of many empirical studies suggest that many L2 learners often prefer to use the web-based instruction activities that include both synchronous and asynchronous forms of teaching L2 lexical items (Kamyab, 2007). According to Ligorio (2001), the instruction resources of web-based vocabulary process can accomplish different types of learners' expectations and enhance the students' participation with different abilities and proficiencies (Khany, \& Khosravian, 2013).

Considering the L2 lexical instruction in Iran, most EFL teachers prefer to decrease the utility of traditional approaches and enhance the use of technology-based learning approaches (Khazai \& Dastjerdi, 2011). In fact, in Iranian setting, web-based CALL programs are not performed unless they are required even when it comes to L2 vocabulary teaching. Therefore, the question is whether there is a possibility that web-based CALL programs are more effective than the traditional face-to-face vocabulary teaching strategies? This paper aims to address this question through a 
critical investigation of the efficacy of web-based language instruction on Iranian EFL learners' level of L2 lexical knowledge.

\section{A. Vocabulary Learning and Technology}

In L2 learning process, Ellis (1994) stated that vocabulary teaching/learning is a very complicated and challenging process. As such, L2 learners do their best to find out the vocabulary learning technique that is more beneficial for them. However, memorizing the new vocabulary item is their first approach in vocabulary learning. Clearly, beginner learners prefer to learn items separately by using a list of word items to memorize, whereas advanced learners attempt to acquire words in their context (Akhlaghi \& Zareian, 2015). In general, presenting new words without paying attention to the learner's background knowledge is one of the limitations in teaching vocabulary items. Accordingly, computers have been provided diversity of activities and better opportunities for learners and teachers to master this limitation. The significant impact of computer-assisted instruction on developing reading comprehension skills and learning lexical items has been reported in numerous studies.

Considering the vocabulary instruction through technology, many practitioners of the field (e.g. Dodigovic, 2005; Yoshii, 2003) have claimed that vocabulary has been one of the most commonly taught language areas through technology in recent years. Genc (2012), for example, states that the rapid dramatic advancements in computer technologies have been affecting all aspects of language learning in general and vocabulary component in particular for more than two decades. Genc also believes that among the most important L2 learning areas that have been affected by this huge improvement are the reading skill and lexical items.

Gorjian, Moosavinia, Ebrahimi and Hydarei (2011) state that vocabulary teachings are in line with the profound changes taking place in other areas of knowledge and advances in network technologies. The researcher further claims that this has resulted in the emergence of virtual worlds designed to facilitate synchronous (online), rather than asynchronous (offline), learning activities and practices among students (Gotjian, et al, 2011). As such, it can be claimed that technology can be employed to help students and teachers learn and teach L2 vocabulary items more effective. According to Long and Doughty (2009), technology can be used to increase the quality of input, to provide useful corrective feedback and train students in the use of technological advances that are fundamental skills in learning another language vocabulary items. Generally, some examples about mixing technology and education in the classroom are having computers to access the internet, using mp3 players and etc. Computer-assisted and online vocabulary learning contexts have proved to be of great help to EFL learners, which are discussed in detail in the following sections (Zimmerman, 1997).

\section{B. Computer-assisted Vocabulary Learning}

Recently, the focus of research has been placed on designing of computer software program which is very practical for self study mode to practice and test vocabulary items. L2 learners construct connections between the verbal and visual representational systems by using multimedia vocabulary learning environments (Mayer \& Sims, 1994). This would contribute to an enhancement of efficient practice for speed of frequent word discovery in vocabulary knowledge (Tozcu \& Coady, 2004).

Based on the teaching context and L2 students' needs, these multimedia word learning environments may take different shapes (Abraham, 2008). Sun and Dong (2004) showed the importance of appealing framework for vocabulary study when authoring a vocabulary learning environment geared at young learners. However, they emphasized the fact that the appeal of the learning environment will not guarantee more effective L2 vocabulary learning without providing proper learning support (cited in Zapata \& Sagarra, 2007).

Similarly, it is pointed out that multimedia-assisted vocabulary learning with the use of static pictures has higher effect than the use of mental effort and as a result, students who used text and video annotations scored lower on the follow-up vocabulary test than students who used the text and picture annotations (Yusuf and et al, 2014).

\section{Web-based Instruction and Online Vocabulary Learning System}

Many researchers and practitioners have pointed to the importance of computer technology (e.g., Guthrie \& Richardson, 1995; Chang \& Lehman, 2002 cited in Son, 2001). According to Smith (2004), computer technology can provide students with the means to construct meaning, to control their own learning and to evaluate and monitor their own performance. In general, it focuses on multimedia computers and the Internet as two important multimedia developments. In L2 learning process, learners prefer to apply various technological tools or hypermedia (Sokmen, 1997).

Among the various existing technological tools, weblogs have attracted the attention of many scholars (e.g., Glen, 2003; Richardson, 2004 cited in Shahivand, \& Pazhakh (2012)). Weblogs are a relatively recent and quickly expanding form communication and publishing on the Internet. As an example, web-based learning is going to become a needed part of learning in-class, teacher-led education. This is because blogs allow individuals to develop personal content and connect with an online community, which enable them to collaborate and share knowledge (Shafaei \& Abdul Rahim, 2015).

The researchers pay attention to Web-based language learning (e.g. Dlaska, 2002; Lin \& Hsu, 2001; Liou, 2001; Liou \& Yang, 2002; Sun, 2003). Web-based language learning involves using of the Web and contains Web materials, 
resources, applications or tools (Son, 2007). Web-based activities which designed well allow teachers to practice with their students individually or in small groups (Cited in Bagheri and et al, 2012).

There are many studies as an example to investigate the effect of web-based instruction on language learning. Like, Stepp-Greany (2002) who examined using multimedia for language instruction. As a result she found that most of the students agreed that multimedia environment was facilitated the language instruction. In the result of another study, AlJarf (2004) investigated Web-based instruction as a supplement has significant effects on writing structure. Kahn (1997) introduced eight frameworks for meaningful learning in Web-based learning; Pedagogical; Technological; Interface design; Evaluation; Management; Resource Support; Ethical and Institutional. Later, Kahn (2001) proposed a framework for using Web- based instruction ranging from "macro" to "micro" uses.

\section{Empirical Studies on Web-based Vocabulary Learning}

Most of the researchers who have studied web-based learning approach have the same idea about positive and efficient effects of that in enhancing vocabulary knowledge. Same studies done by Zhang, Song and Burston (2011) and Khazaei and Dastjerdi (2011) a comparative study on the impact of traditional and computer-assisted language learning approaches on Chinese and Iranian EFL learners' vocabulary acquisition and retention. The study aimed to explore the application of online and web-based instruction to the teaching of L2 vocabulary. Whereas one group of students studied a selected list of vocabulary via web-based activities, the other group worked on the same list through paper material. The results showed that students can learn vocabulary more effectively short-term via online activities than with paper material and the students who received the learning content through web-based approach were better than the students who received the learning content in the traditional way.

Web-based instruction offers multiple dimensions of using in EFL teaching and learning. Since vocabulary learning is an indispensable and time consuming part of language learning, numerous efforts have been made to facilitate and enhance the complex process of vocabulary learning (Read and et al, 2013). Veda Aslim Yetis (2010), for example, conducted a study which focused on learning vocabulary by Web-based instruction. His samples were 17 Turkish students who studied French. The students were taught Vocabulary by traditional way for a month and then participated in exams. In the following month the lessons were conducted via the Internet on the web site. Again the students took part in some exams. Results showed that the average scores obtained from exams made after each class has risen when the Internet was used (Khany \& Khosravian, 2013).

\section{RESEARCH METHOD}

The research design included pre and post-tests. The experimental group was instructed using web-based language learning and the control group used the ordinary classroom instruction of learning vocabulary. The independent variable is using web as a facilitative device and the dependent variable is improving vocabulary knowledge of the learners. In order to probe the research questions, the following hypotheses are formulated:

H1: Web-based vocabulary instruction strategies have a significant effect on the Iranian EFL learners' level of L2 lexical knowledge.

H2: The Iranian EFL learners have a positive attitude towards the use of web-based vocabulary learning activities and strategies in their language class.

Procedure

In the learning phase, the participants learn their course vocabularies making use of free vocabulary learning sites of IELTS English language learning site every day for 8 weeks. The classes were held two sessions a week, each session one hour and a half in the school computer room; every session 10 new words were introduced to the learners. There is an option for them to choose the number of words to review each session. The learners should review at least 10 words a session, but they can increase this number according to their own pace.

As a homework practice, the students had the chance to use the IELTS vocabulary learning sites which were an instrument in teaching procedure. So, Students could have access to computers every day. They were informed that IELTS vocabulary learning website is free and they can use their laptops at home individually. The students in control group received ordinary classroom instructions each session. In the control group, the same textbook vocabularies were taught through synonyms, exemplifications and practicing vocabulary. So as to teach the new vocabularies, the learners should close their books and follow the steps. First reading aloud each vocabulary items two or three times, then, having a short pause so that the students understand the correct pronunciation.

The next step is also reading out each vocabulary two or three times again and permitting the students to repeat the words. In the third step the students open their books to the intended page and only listen to the teacher as the vocabulary items were read out to them. The last step is illustrating each word from word list and writing the synonyms and antonyms on the board.

In order to ensure the homogeneity of the students, a modified Michigan test (version1997) was presented among 100 intermediate learners to select 66 male and female students at the same level of proficiency. Then, they were divided into one experimental group $(\mathrm{n} 1=33)$ and one control group $(\mathrm{n} 2=33)$. As for the receptive vocabulary learning, in the pretest phase the learners were asked to take the Nation's 14000 version Vocabulary Size Test (1000, 2000 and 3000 word family level, each level having ten questions). 
The participants in experimental group learned their course vocabularies making use of free vocabulary learning sites of IELTS English language learning site every day for 8 weeks. IELTS vocabulary learning section helps learners to review target words for a short period of time every by spaced repetition learning system. Students had access to computers every day. They were informed that IELTS vocabulary learning website is free and they can use their laptops at home individually. The students in control group received ordinary classroom instructions each session.

The posttest was administered to experimental and control groups at the end of the course. The Nation's 14000 version Vocabulary Size Test (1000, 2000 and 3000 word family level, each level has ten questions) was utilized to measure the receptive vocabulary size. Finally, in the last session, in order to investigate learners' perspectives on Web based vocabulary learning the questionnaire was administered.

\section{RESULTS}

\section{Data Analysis}

The data of the study were achieved by analyzing the pre and posttest scores as well as the questionnaire. To achieve reliable result, both descriptive and inferential data were used to assess the improvement of one group of learners over the other in vocabulary acquisition. To this goal, some statistical analysis such as mode, mean, standard deviation, correlation, and t-test were used.

The required data was collected using the standardized test of Nation "es 14000 versions Vocabulary Size (1000, 2000 and 3000 word family level, each level has ten questions) before and after the intervention for all control and experimental group. Also, the questionnaire from Altiner (2011) and Bulut \& Farhan (2007) was administered to the participants to investigate their perception about WB vocabulary teaching method.

Then, the researcher applied the independent sample T-test SPSS 19 procedure. The independent sample T-test procedure compute the probable effect of one variable on the other one. To evaluate whether the means for two independent groups are significantly different from each the independent-samples $t$ - test was done. That is commonly referred between groups design and can also be used to analyze a control and experimental group.

For more clarification of the positive effect of websites on vocabulary development of EFL learners, the acquired results of pre-and posts of experimental group are compared in table 3.1 through independent sample t-test. Table 3.1 outlined the values of means and standard deviation along with standard error of the mean for the two vocabulary size tests. The mean score of the post-test was 1.0000 points higher than that of the pre-test.

TABLE 3.1:

INDEPENDENT SAMPLES T-TEST FOR VOCABULARY SIZE PRE-POST-TEST GRADES OF EFL PARTICIPANTS

\begin{tabular}{|c|c|c|c|c|c|c|c|c|c|}
\hline \multirow[t]{3}{*}{$\begin{array}{l}\text { Independent } \\
\text { Samples Test }\end{array}$} & \multicolumn{2}{|c|}{$\begin{array}{l}\text { Levene's Test for } \\
\text { Equality of Variances }\end{array}$} & \multicolumn{7}{|c|}{ T-test for Equality of Means } \\
\hline & \multirow[t]{2}{*}{$\mathrm{F}$} & \multirow[t]{2}{*}{ Sig. } & \multirow[t]{2}{*}{$\mathrm{T}$} & \multirow[t]{2}{*}{ Df } & \multirow[t]{2}{*}{$\begin{array}{l}\text { Sig. (2- } \\
\text { taild) }\end{array}$} & \multirow[t]{2}{*}{$\begin{array}{l}\text { Mean } \\
\text { Difference }\end{array}$} & \multirow[t]{2}{*}{$\begin{array}{l}\text { Std. Error } \\
\text { Difference }\end{array}$} & \multicolumn{2}{|c|}{$\begin{array}{l}95 \% \text { Confidence Interval of } \\
\text { the Difference }\end{array}$} \\
\hline & & & & & & & & Lower & upper \\
\hline $\begin{array}{l}\text { Equal variances } \\
\text { assumed }\end{array}$ & 1.310 & .260 & -4.624 & 38 & .000 & -1.00000 & .21628 & -1.43783 & -.56217 \\
\hline $\begin{array}{l}\text { grade equal } \\
\text { variances not } \\
\text { assumed }\end{array}$ & & & -4.624 & 37.263 & .000 & -1.00000 & .21628 & -1.43812 & -.56188 \\
\hline
\end{tabular}

The independent sample T-test procedure offered two tests of the comparison between the pre and post-tests. The significance index of the Levene statistic was .260 (greater than .05); it could be assumed that the both tests had equal variances. Based on Table 3.1, there was a significant difference ( $\operatorname{sig} 2$ tailed $=.000$ ) between the mean differences of the vocabulary size test scores of participants before and after the treatment in terms of their vocabulary development tests because the Sig (2-Tailed) value is less than.05. So, we can conclude that there is a statistically significant difference between two conditions $(\mathrm{p}<0.05)$.

The second section of the questionnaire was used to determine participants' reworks, attitudes and feelings about the WB vocabulary teaching through 10 Likert-scale items. This test was administered in the last session. Both sections of the questionnaire were adopted from Altiner (2011) and Bulut \& Farhan (2007) respectively.

These acquire numerical measurements of questionnaire and Nation "e 14000 version Vocabulary Size Test were correlated through Pearson-moment-correlation test coefficient $(r)$ to assess the degree that quantitative variables are linearly related in a sample. The values of the Pearson Correlation range from -1 to +1 with negative numbers describing a negative correlation and positive numbers describing a positive correlation. The closer the value is to -1 or +1 , the stronger the association is between the variables. In this research, the researcher hypothesized a positive relationship between the learners Vocabulary Size Test scores and their attitudes towards the use of web in the language class. 
TABLE 3.2

CORRELATIONS

\begin{tabular}{|c|c|c|c|}
\hline & & Vocabulary size test & QT \\
\hline \multirow{3}{*}{$\begin{array}{l}\text { Vocabulary } \\
\text { size test }\end{array}$} & Pearson Correlation & 1 & .952 \\
\hline & Sig. (2-tailed) & & .000 \\
\hline & $\mathrm{N}$ & 66 & 30 \\
\hline \multirow[t]{3}{*}{ QT } & Pearson Correlation & .952 & 1 \\
\hline & Sig. (2-tailed) & .000 & \\
\hline & $\mathrm{N}$ & 66 & 30 \\
\hline
\end{tabular}

As it is shown in table 3.2, there were statistically significant correlations (The $p$-value, Sig.000 $<.01$ ) between learners' vocabulary post-tests results and questionnaire acquired results.

\section{DISCUSSION}

Regarding the research question, students' attitudes toward the incorporating web as a facilitative device on the vocabulary development of the learners has come to an answer that students in general have developed a positive attitude toward using web based education. Recently, conventional computer-assisted language learning (CALL) has gradually out striped web-based language learning (WBLL) (Son, 2008).

These findings are in line with Sampson (2003) who believed that web-based education includes learning independently by using self-study texts and asynchronous communication. Participants who use Internet for ESL learning had positive attitudes toward web-based language learning (WBLL) and they showed that to be interested in additional activities in and outside class time (Son, 2008).

The findings of the study also support many researchers' claims in terms of the learners' perception after using a computer-based program for increasing the speed and amount of vocabulary. The results of current study are compatible with those achieved by Altiner (2011). This result is also supported by other researchers who have shown that technology and learning are related correspondingly and students have tend to use different technologies and also technology use can generate positive attitudes in learners (Oblinger, 2005).

Ghabanchi and Anbarestani (2008) described the effects of a CALL program on expanding lexical knowledge of EFL Iranian intermediate learners. The result shows CALL produced better gains in contextualized vocabulary learning plus better pronunciation. Naraghizadeh and Barimani (2013) explained the effectiveness of CALL on Iranian EFL learners' vocabulary learning and his findings indicated a significant difference between experimental and control group with regard to their vocabulary knowledge. CALL instruction enhanced EFL learners' vocabulary knowledge.

\section{CONCLUSION}

The prime goal of the current study was to investigate learning vocabulary via web based vocabulary learning software by Intermediate EFL students in Iran and its contribution to learners' perception. The result appeared to manifest that learners' perception improved by incorporating web based instruction in language learning classroom. The findings indicated a significant difference between experimental and control group with regard to their vocabulary knowledge. WBL instruction enhanced EFL learners' vocabulary knowledge.

\section{A. Pedagogical Implications}

From a pedagogical perspective, the findings of this study may offer some implications for language teaching and learning. To begin with, these findings can be beneficial for language learning curriculum designers to present tasks that enrich both the language of the students and their motivation to apply on-line web sites for autonomous learning of language. The experience with computers is an influential factor in instructors' personal views of computer integration. Students through English learning web sites have numerous opportunities such as reflecting on studying through authentic materials and communicating with their companions from all over the world via chat programs (GodwinJones, 2011).

\section{B. Suggestions for Further Research}

This study can be repeated to find out whether the same results would be obtained or not. While the study focused on vocabulary learning as the predicted variable, it is suggested to take other skills into account in other researches. Since different age groups have different personality features, the same study could be carried out among students at different age range and language proficiency levels. Future research may examine computerized instruction on different language skills such as reading and writing.

\section{REFERENCES}

[1] Abu Bakar, N., \& Nosratirad, E. (2013). Sustaining vocabulary acquisition through computer game: A case Study. Asian Social Science, 9(5), 1911-2017. http://dx.doi.org/10.5539/ass.v9n5p235.

[2] Ahmadian, M., Amerian, M., \& Goodarzi, A. (2015). A Comparative study of paper-based and computer-based contextualization in vocabulary learning of EFL students. Advances in Language and Literary Studies, 6(2), 96-97. 
[3] Aist, G. (2002). Helping children learn vocabulary during computer-assisted oral reading. Journal of Educational Technology \& Society, 5(2), 147-163.

[4] Akhlaghi, M., \& Zareian, G. (2015). The effect of power point presentation on grammar and vocabulary learning of Iranian pre-university EFL learners. Academic Research International, 6(1), 160-165.

[5] Al-Jarf, R. (2007). Teaching Vocabulary to EFL College Students Online. CALL-EJ Online, 8(2), Retrieved 13 May 2015 from: http://callej.org/journal/8-2/al-jarf.html. .

[6] Bagheri, E. \& Roohani, A. \& Nejad Ansari, D. (2012). Effect of CALL-based and Non-CALL Based Methods of Teaching on L2 Vocabulary Learning. Journal of Language Teaching and Research, 3(4). pp. 744-752, July 2012.

[7] Bell, C. (1998). Everone "es using the Web, so why aren"et we?: Web design and the ESOL teacher. CAELL Journal, 8(4), 8-12.

[8] Brown, T. S., \& Perry, F. L. Jr. (1991). A comparison of Three Learning Strategies for ESL Vocabulary Acquisition, TESOL Quarterly, 25, 655-670.

[9] Chang, M. M. (2007). Enhancing web-based language learning through self-monitoring. Journal of Computer Assisted Learning, 23, 187-196.

[10] Chun, D. M., \& Plass, J. L. (2000). Networked multimedia environments for second language acquisition. In M. Warschauer \& R. Kern (Eds.), Network-based language teaching: Concepts and practice (pp. 151-170). New York: Cambridge University Press.

[11] Fahim, F., Motallebzadeh, Kh. \& Sazegar, Z. (2011). The Effect of E-mailing on Vocabulary Retention of Iranian Lower Intermediate EFL Learners. Journal of Language Teaching and Research, 5(2), 1385-1391.

[12] Felix, U. (2001). Research: Absolutely worth the effort! In U. Felix (Ed.), Beyond Babel: Language learning online (pp. 299365). Melbourne: Language Australia.

[13] Gorjian, B., Moosavinia, S.R., Ebrahimi Kavari, K., Asgari, P., \& Hydarei, A. (2011). The impact of asynchronous computerassisted language learning approaches on English as a foreign language high and low achievers' vocabulary retention and recall. Computer Assisted Language Learning, 24(5), 383-391.

[14] Hadid Tamjid, N. \& Saber Moghadam, S. (2012). The Effect of Using Vocabulary Teaching Software on Iranian Intermediate Efl Learners" Vocabulary Acquisition. World Applied Sciences Journal 19 (3): 387-394, 2012.

[15] Jia, J., Chen, Y., Ding, Z., \& Ruan, M. (2012). Effects of a vocabulary acquisition and assessment system on students ${ }^{\text {ee }}$ performance in a blended learning class for English subject. Computers \& education, 58, 63-76. http://dx.doi.org/10.1016/j.compedu.2011.08.002.

[16] Jang, S. J. (2006). The effects of incorporating web - assisted learning with team teaching in seventh - grade science classes. International Journal of Science Education, 28(6), 615- 632.

[17] Kamyab, S. (2007). An Overview of the Education System of Islamic Republic of Iran. 8 February, 2014, from http://handouts.aacrao.org/am07/finished/F0345p_S_Kamyab.pdf.

[18] Khany, R \& Khosravian, F. (2014). Iranian EFL Learners"e Vocabulary Development through Wikipedia. English Language Teaching; 7(7) ; 2014.

[19] Khany, R., \& Khosravian, F. (2013). The application of Wikipedia for enhancing Iranian EFL students ${ }^{\text {ee }}$ reading proficiency (pp 135-142). Proceeding of the global summit on education 2013 (GSE2013). Kuala Lumpur, Malaysia.

[20] Khazai, S., Vahid dastjerdi, H., \&Talebi Nejhad, M. R. (2011). The role of mobile communications technology in teaching and learning English vocabulary. Journal of Technology of Education, 6(2), 135-142.

[21] Mansouri, V. (2015). Vocabulary instruction: Software flashcards vs. word clouds. Advances in Language and Literary Studies, $6(1), 41-45$.

[22] McGlinn, J., \& Parrish, A. (2002) Accelerating ESL students' reading progress with accelerated reader. Reading Horizons, 42(3), 175-189.

[23] Negash, S., Wilcox, M. V., \& Emerson, M. (2007). Synchronous hybrid e-learning: Teaching complex information systems classes online. International Journal of Information and Communication Technology Education, 3(3), 1-13.

[24] Rashtchi, M. \& Aghili, H. (2014). Computerized Input Enhancement versus Computer-assisted Glosses: Do They Affect Vocabulary Recall and Retention? Theory and Practice in Language Studies, 4(8), pp. 1665-1674, August 2014.

[25] Read, D., Coles, S., Frey, J., \& Littlefield, B. (2013). Investigating the use of Virtual Learning Environments by teachers in schools and colleges. Available online at: http://eprints.soton.ac.uk/342377/1/DRead_VLE_report.pdf (accessed 4 March, 2013).

[26] Reyna, C., Feng, Y. L., \& Nzai, V. E. (2012). Cyber reading workstations: The Pandora"s vocabulary teaching strategy for elementary Mexican-American students in South Texas. Journal of Modern Education Review, 4(5), 311-326. http://dx.doi.org/10.15341/jmer(2155-7993)/05.04.2014/001.

[27] Saslow J. M., Ascher A. (2011c). Summit 2A. London: Pearson Education. Shahrokni, S. A. (2009). Second language incidental vocabulary learning: The effect of online textual, pictorial, and textual pictorial glosses. TESL-EJ, 13(3), 1-17.

[28] Shafaei, A. (2008). Review of English Teaching Methodologies: Obstacles of Implementing New Methods in Iran. Paper presented at the Global Practices of Language Teaching: Proceedings of the 2008 International Online Language Conference (IOLC 2008).

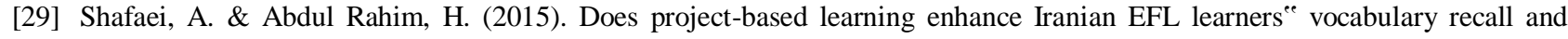
retention?. Iranian Journal of Language Teaching Research 3(2), 83-99.

[30] Shahivand, Z., \& Pazhakh, A. (2012). The effects of test facets on the construct validity of the tests in Iranian EFL students. Higher Education of Social Science, 2(1), 16-20.

[31] Talang, T. \& Mahmoodi, M.H. (2013). The Effect of Using Word Clouds on EFL Students ${ }^{\text {ee }}$ LongTerm Vocabulary Retention. Journal of English Language Teaching and Learning No. 11, 2013, 4-9

[32] Tamjid, N. H., \& Moghadam, S. S. (2012). The effect of using vocabulary teaching software on Iranian intermediate EFL learners' vocabulary acquisition. World Applied Sciences Journal, 19(3), 387-394.

[33] Tozcu, A., \& Coady, J. (2004). Successful learning of frequent vocabulary through CALL also benefits reading comprehension and speed. Computer Assisted Language Learning, 17(5), 473-495. http://dx.doi.org/10.1080/0958822042000319674. 
[34] Yunus, M. and et al. (2016). Impact of Using CALL on Iranian EFL Learners' Vocabulary Knowledge. English Language Teaching; 9(1), 3-7

[35] Yusuf, M. A., Sim, T. S., \& Su"ead A. (2014). Studentsee proficiency and textual computer gloss use in facilitating vocabulary knowledge. English Language Teaching, 7(11), 99-107. http://dx.doi.org/10.5539/elt.v7n11p99.

[36] Zahedi, Y., \& Abdi, M. (2012). The effect of semantic mapping strategy on EFL learners" vocabulary learning. Procedia Social and Behavioral Sciences, 69, 2273-2280.

[37] Zapata, G., \& Sagarra, N. (2007). CALL on hold: The delayed benefits of an online workbook on L2 vocabulary learning. Computer Assisted Language Learning, 20(2), 153-171. http://dx.doi.org/10.1080/09588220701331352

[38] Zimmerman, C. B. (1997). Historical trends in second language vocabulary instruction, In J. Coady \& T. Huckin (Eds.), Second language vocabulary acquisition, Cambridge: Cambridge University Press.

Mustapha Hajebi is an English language teacher in Department of Education, Bandar Abbas, Iran. He finished his undergraduate studies at Tehran University for Teacher Education, majoring in TEFL. He continued his graduate studies at Islamic Azad University of Bandar Abbas, where he got his M.A degree in TEFL. His research interests include Second Language Teaching, Applied ELT, Speaking, Collocations and Educational Technology.

SeddiQ Taheri is an English language teacher in Department of Education, Fars, Iran. He finished his undergraduate studies at Tehran University for Teacher Education, majoring in TEFL. He continued his graduate studies at University of Yazd, where he got his M.A degree in TEFL. His research interests include Listening, Collocational Competence and Writing.

Farhad Fahandezh is a Professor and Supervisor in Islamic Azad University of Bandar Abbas, Iran, where he teaches courses in Language Testing, Research Methodology, Teaching Methodology, Linguistics, and Philosophy of Education. He got his P.hD degree in TEFL at University of Malaya, Malaysia. His research interests center on inter language pragmatic instruction, Second Language Teaching and assessment, language and culture.

Hosain Salari is an English language teacher in Department of Education, Kerman, Iran. He finished his undergraduate studies at Tehran University for Teacher Education, majoring in TEFL. He continued his graduate studies at Islamic Azad University of Bandar Abbas, where he got his M.A degree in TEFL. His research interests include Education, Technology and listening. 